\title{
Relationship between Depression and Psychological Well-being of Students of Professional Courses
}

\author{
Pragya Tiwari ${ }^{1}$, Dr. Nishi Tripathi ${ }^{2}$
}

Keywords: Depression, Psychological Well-being, Professional Courses.

The aim of the present research is to study the 'Relationship between Depression and Psychological Well-being of Students of Professional Courses'. The psychological well-being of professional students is a very important component in the training and development in present and future for their career. The present study investigated the relationship between psychological well-being and depression of students of professional courses.

Depression is very common disorder in our society. It is a negative aspect of well-being. In 2002, depression accounted for $4.5 \%$ of the worldwide total burden of disease (in terms of disability-adjusted life years). World Health Organization's World Mental Health Survey Initiative has said that India has the highest rate of major depression in the world in 2011. Indians are among the world most depressed individuals. According to a World Health Organization-sponsored study, while around 9\% of people in India reported having an extended period of depression within their lifetime, nearly 36\% suffered from what is called Major Depressive Episode, WHO’s World Health Survey (ICD-10).

In India, there is scarcity of research on prevalence and factors influencing depression among elderly. (Sanjay T V \& Jahnavi R).

Depression is a state of low mood and aversion to activity that can affect a person's thoughts, behavior, feelings and physical well-being. Depressed people may feel sad, anxious, empty, hopeless, worried, helpless, worthless, guilty, irritable, or restless. The individual may lose interest in activities that were pleasurable; experience loss of appetite or overeating; have problems concentrating, remembering details, or making decisions; and may contemplate, attempt, or even desire suicide. Insomnia, excessive sleeping, fatigue, loss of energy, or aches, pains or digestive problems that are resistant to treatment may be present. Some people describe

${ }^{1}$ Research Scholar of Department of Psychology, Shiats, Sam Higginbottom Institute Of Agriculture, Technology And Scinces, Allahabad

${ }^{2}$ Associate Professor of Department of Psychology, Shiats, Sam Higginbottom Institute Of Agriculture, Technology And Scinces, Allahabad

(C) 2015 I P Tiwari; licensee IJIP. This is an Open Access Research distributed under the terms of the Creative Commons Attribution License (http://creativecommons.org/licenses/by/2.0), which permits unrestricted use, distribution, and reproduction in any Medium, provided the original work is properly cited. 
depression as "living in a black hole" or having a feeling of impending doom. However, some depressed people do not feel sad at all, they may feel lifeless, empty, and apathetic, or men in particular may even feel angry, aggressive, and restless.

In 2002 Dianne A. \& Van, used question whether the Beck Depression Inventory (BDI), which is one of the most widely used instruments to assess depression, can be used to measure differences in subjective well-being at national level. He found depression negatively correlated with subjective well-being and other happiness-related variables. These findings suggest that depression had the same meaning at individual and country level and that depression is an adequate measure of (a lack of) well-being at country level.

Wellbeing is a notion that people and policymakers generally aspire to improve. However, it is an ambiguous concept, lacking a universally acceptable definition and often faced with competing interpretations (Akerlof, George A. 2007). Wellbeing is generally viewed as description of the state of people's life situation (McGillivray 2007, p. 3). Well-being is a dynamic concept that includes subjective, social and psychological dimensions as well as health related behavior. (Spring 2005).

\section{A theoretical model of psychological well-being encompasses 6 distinct dimensions of wellness.}

The Ryff Scales of Psychological Well-Being is a theoretically grounded instrument that specifically focuses on measuring multiple facets of psychological well-being. These facets include the following:

Autonomy: I have confidence in my opinions, even if they are contrary to the general consensus. Environmental Mastery: In general, I feel I am in charge of the situation in which I live.

Personal Growth: I think it is important to have new experiences that challenge how you think about yourself and the world.

Positive Relations with Others: People would describe me as a giving person, willing to share my time with others.

Purpose in Life: Some people wander aimlessly through life, but I am not one of them.

Self-Acceptance: I like most aspects of my personality (Carol Ryff 1995)

\section{OBJECTIVE:}

- To study the level of depression among students of professional courses.

- To find out the psychological well-being of the students of professional courses.

- To find out the relationship between depression and psychological well-being.

\section{HYPOTHESIS:}

- There will be a significant difference between ages with psychological well- being.

- There will be a significant difference between genders with psychological wellbeing.

- There will be a significant relationship between depression and psychological wellbeing. 


\section{METHODOLOGY:}

\section{Sample:}

The sample of study consists of 100 students of professional courses master in business administration, master in computer application and master in tourism administration (M.B.A., M.C.A. and M.T.A) from BHU (35 male and 65 female) in the age range of 20 to 28 years(mean=23.55).

\section{Tools:}

1. The Beck Depression Inventory (Beck, A.T., 1996)

2. Scale of Psychological Well-being (Carol Ryff 1995)

\section{The Beck Depression Inventory (BDI):}

There are 20 question inventory and every questions have four options. It has four point scales ranging from 0 to 3 . In first option respondent gains 0 marks, second option respondent gains 1 mark and third option respondent gains 2, fourth option respondent gains 3 marks. The total scores of 20 questions shows depression level, there are four parts of depression based on the score gained. High scores show high depression and low score shows low depression.

\section{Reliability and validity:}

Alpha reliability coefficients range from- 0.79 to 0.95 in psychiatric samples and from 0.3 to 0.90 in non-psychiatric samples inducting that the BDI has good internal consistency.

\section{Scale of Psychological Well-being Carol Ryff:}

The Ryff scale of psychological well-being is a theoretical grounded instrument that specially focuses on measuring multiple facets of psychological well-being. These facets include the following.

\section{Reliability:}

Internal consistency of 3 item scale.

1. Autonomy: Reliability is (.37).

2. Environmental mastery: Reliability is (.49)

3. Personal growth: Reliability is (.40)

4. Positive relations: Reliability is (.56)

5. Purposeful life: Reliability is (.33)

6. Self-acceptance: Reliability is (.52)

\section{Procedure:}

The study was conducted on 100 students (35 male and 65 female) in the age range of 20 to 28 years (mean=23.55, SD=1.91). The sample was randomly selected from master in business administration, master in computer application and master in tourism administration (MCA, MBA \& MTA) from Banaras Hindu University (BHU). BDI-I and psychological well-being scale was individually administered to each respondent. After a formal introduction, the scale 
was filled by them, and the duly filled in scales were collected with a word of thanks for their support. When all response sheets were collected, scoring and data analysis was completed. Descriptive statistics (Mean, Standard Deviation, t value and correlation) were used for the analysis of data. On the basis of their scores and socio-demographic detail, some suitable tips were given to maintain their well-being and coming out of depression.

\section{RESULT:}

Table-1 Demographic variable: Gender of students of professional courses

\begin{tabular}{|l|l|l|}
\hline & Frequency & Percent \\
\hline Male & 35 & 35.0 \\
\hline Female & 65 & 65.0 \\
\hline Total & 100 & 100.0 \\
\hline
\end{tabular}

Table-2 presents gender of the students of professional courses. The findings of the table presenting that there were equal distribution of gender (male $=35 \%$, Female $=65 \%$ ).

Table-2: Correlation between Age and gender with Psychological Well-being

\begin{tabular}{|c|c|c|c|c|c|c|c|}
\hline 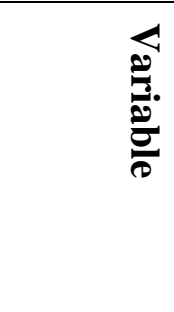 & 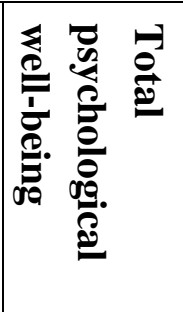 & 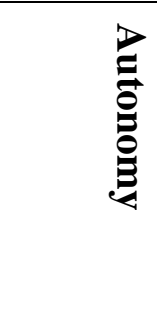 & 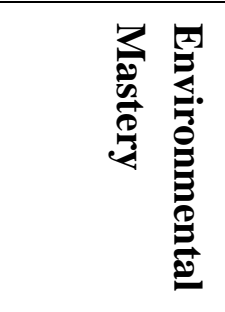 & 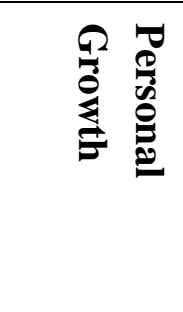 & 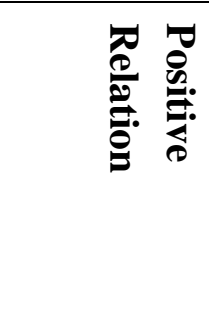 & 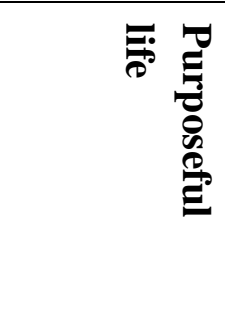 & 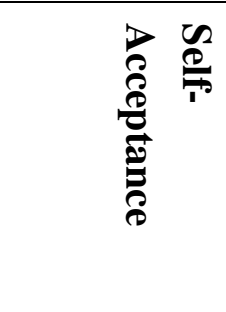 \\
\hline Age & -.188 & -.56 & -.196 & -.108 & -.03 & -.036 & $-.231^{*}$ \\
\hline Gender & .194 & .094 & .158 & .137 & .034 & -.097 & $.287^{*}$ \\
\hline
\end{tabular}

** Significant at the 0.01 level

*Significant at the 0.05 level

The findings of table- 2 present the correlation between age, gender and psychological wellbeing. The table indicates that there is a negative correlation between age and self-acceptance ( $r=$ $-.231)$ at .05 level of significance, which suggest that student with increasing age reported in selfacceptance.

The table further indicates that there is a positive correlation between gender and self-acceptance $(r=-.231)$ at .05 level of significance, which suggest that female students reported high in selfacceptance. 
Table-3: Correlation between depression and Psychological Well-being.

\begin{tabular}{|c|c|c|c|c|c|c|c|}
\hline 音. & 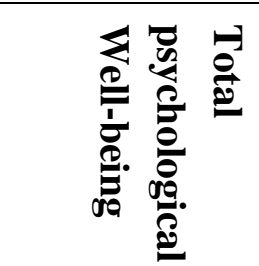 & 苞 & 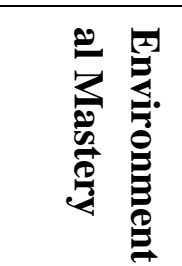 & $\begin{array}{ll}0 & 0 \\
0 & 0 \\
0 & 0 \\
0 & 0 \\
\Xi & 0\end{array}$ & 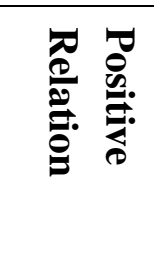 & 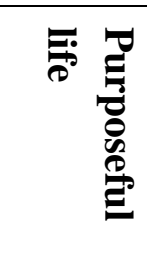 & 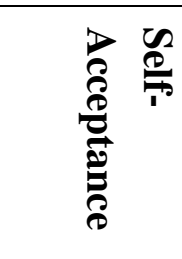 \\
\hline Depression & $-.254 * *$ & $-.264 * *$ & -.074 & .081 & $-.212^{*}$ & -.101 & $-.345 * *$ \\
\hline
\end{tabular}

** Significant at the 0.01 level

* Significant at the 0.05 level

The findings of table-3 present the correlation between depression and psychological well-being. The table indicates that there is a negative correlation between depression and total well-being $(r=-.254)$ at .01 level of significance, which suggest that students with low depression reported high in total psychological well-being. The table further indicates that there is a negative correlation between depression and autonomy dimension of psychological well-being $(r=-.264)$ at .01 level of significance, which suggest that students with low depression reported high in autonomy dimension of psychological well-being. The table further indicates that there is a negative correlation between depression and positive relation dimension of psychological wellbeing $(\mathrm{r}=-.212)$ at .05 level of significance, which suggest that students with low depression reported high in positive relation dimension of psychological well-being. The table further indicates that there is a negative correlation between depression and self-acceptance dimension of psychological well-being $(r=-.345)$ at .01 level of significance, which suggest that students with low depression reported high in self-acceptance dimension of psychological well-being.

Table-4: Mean, SD and t value of depression with gender variable

\begin{tabular}{|l|l|l|l|l|l|l|}
\hline Variable & Gender & $\mathbf{N}$ & Mean & SD & $\mathbf{T}$ & $\mathbf{P}$ \\
\hline \multirow{2}{*}{ Depression } & Male & 35 & 6.80 & 4.714 & -1.450 & 0.05 \\
\cline { 2 - 7 } & Female & 65 & 5.40 & 4.548 & & \\
\hline
\end{tabular}

Table-4 presents the comparison between depression and gender variable. The finding of the table indicates that the $t$ value for depression (-1.450) is significant at .05 level which suggests that males (mean $=4.80$, sd $=4.714$ ) reported more neuroticism than females (mean=4.548, $\mathrm{sd}=4.546$ ). This means that males have shown more feeling of low mood and aversion to activity that can have a negative effect on a person's thoughts, behavior, feelings, world view and physical well-being (Salmans, Sandra 1997). 
Table-5: Mean, SD and t value of psychological Well-being with gender variable

\begin{tabular}{|c|c|c|c|c|c|c|}
\hline Variable & Gender & $\mathbf{N}$ & Mean & SD & $\mathbf{T}$ & $\mathbf{P}$ \\
\hline \multirow{2}{*}{$\begin{array}{l}\text { Total } \\
\text { psychological } \\
\text { well-being }\end{array}$} & Male & 35 & 75.77 & 4.714 & \multirow[b]{2}{*}{-1.953} & \multirow[b]{2}{*}{0.05} \\
\hline & Female & 65 & 79.54 & 4.548 & & \\
\hline \multirow{2}{*}{ Autonomy } & Male & 35 & 11.23 & 2.522 & \multirow{2}{*}{-.935} & \multirow{2}{*}{ NS } \\
\hline & Female & 65 & 11.72 & 2.522 & & \\
\hline \multirow{2}{*}{$\begin{array}{l}\text { Environmental } \\
\text { Mastery }\end{array}$} & Male & 35 & 12.94 & 3.086 & \multirow{2}{*}{-1.582} & \multirow{2}{*}{0.05} \\
\hline & Female & 65 & 13.88 & 2.661 & & \\
\hline \multirow{2}{*}{$\begin{array}{l}\text { Personal } \\
\text { Growth }\end{array}$} & Male & 35 & 13.63 & 3.135 & \multirow{2}{*}{-1.368} & \multirow{2}{*}{0.05} \\
\hline & Female & 65 & 14.42 & 2.512 & & \\
\hline \multirow{2}{*}{$\begin{array}{l}\text { Positive } \\
\text { Relation }\end{array}$} & Male & 35 & 12.77 & 2.829 & \multirow{2}{*}{-.339} & \multirow{2}{*}{ NS } \\
\hline & Female & 65 & 12.97 & 3.090 & & \\
\hline \multirow{2}{*}{$\begin{array}{l}\text { Purposeful } \\
\text { life }\end{array}$} & Male & 35 & 13.23 & 3.344 & \multirow{2}{*}{-.968} & \multirow{2}{*}{ NS } \\
\hline & Female & 65 & 12.68 & 2.319 & & \\
\hline \multirow{2}{*}{$\begin{array}{l}\text { Self- } \\
\text { Acceptance }\end{array}$} & Male & 35 & 11.97 & 10.655 & \multirow{2}{*}{-2.970} & \multirow{2}{*}{0.01} \\
\hline & Female & 65 & 13.86 & 8.326 & & \\
\hline
\end{tabular}

Table-5 presents the comparison between psychological well-being and gender. The finding of the table further indicates that the $t$ value for total psychological well-being $(-1.953)$ is significant at .05 level which suggests that females (mean=79.54, sd=4.548) reported more total well-being than males (mean=75.77, sd=4.548). This means that females have shown more Wellbeing is generally viewed as description of the state of people's life situation. The finding of the table further indicates that the $t$ value for Environmental Mastery dimension of psychological well-being (-1.582) is significant at .05 level which suggests that females (mean=13.88, sd=2.661) reported more neuroticism than males (mean=12.94, $\mathrm{sd}=3.086$ ). This means that females have shown more sense of mastery and competence in managing the environment; controls complex array of external activities; makes effective use of surrounding. The finding of the table further indicates that the $t$ value for personal growth dimension of psychological well-being (-1.368) is significant at .05 level which suggests that females (mean=14.42, sd=2.512) reported more personal growth than males (mean=13.63, sd=3.135). This means that males have shown more feeling of continued development; sees self as growing and expanding; is open to new experiences; has sense of realizing his or her potential; sees 
improvement in self and behavior over time; is changing in ways that reflect more selfknowledge and effectiveness. The finding of the table further indicates that the t value for selfacceptance dimension of psychological well-being (-2.970) is significant at .01 level which suggests that females (mean=13.86, sd=8.326) reported more self-acceptance than males (mean=11.97, sd=10.655). This means that males have shown more positive attitude toward the self; acknowledges and accepts multiple aspects of self-including good and bad qualities; feels positive about past life.

\section{CONCLUSION:}

1. In increasing age, professional student's self-acceptance was low.

2. In female's students of professional courses, self-acceptance was high as compared to male students.

3. When depression was high, autonomy, positive relation and self-acceptance dimension of well-being found to be low.

4. Students with depression had many difficulties to accept real condition (often a negative or uncomfortable situation).

\section{REFERENCES:}

Akerlof, George A. (2007). The Missing Motivation in Macroeconomics. American Economic Review 97(1): 5-36.

APA Diagnostic Classification DSM-IV-TR . Diagnostic and Statistical Manual of Mental Disorders, Fourth Edition, Text Revision. Copyright 2000 American Psychiatric Association.

Beck A.T., Steer R.A., \& Brown G. Beck (1996). Beck’s Depression Inventory Scale.

Bradburn; Norman, M. \& Noll S.C.E (1969). The structure of psychological well-being Chicago: Aldine publication \& corporation. Council of International Organization for Medical Science (2000). Biomedical Research Ethics: Updating International Guidelines. Geneva:Author.

Diener, E., Oishi, S., \& Lucas,R. E. (2002). Subjective well-being: The science of happiness and life satisfaction. In C.R. Snyder \& S.J. Lopez (Ed.), Handbook of Positive Psychology. . p. 63 Oxford and New York : Oxford University Press.

Duckworth, A. L.; Steen T. A. \& Seligman M. E. P.(2005). Positive psychology in clinical practice, Annual review of clinical psychology, 1, 629-651.

Erikson, E. (1959). Identify and the life cycle psychological issues, 1: 18-167.

Fournier; Locuise \& Vivianne, Kovess (1993). A comparison of mail and telephone interview strategies of mental health surveys. The conation Journal of psychology, 38(3) 33-255.

Galbraith, G.; Straus M., Jordan Viola \& Cross, H. (1974). Social desirability ratings from males and females: A sexual items . Journal of consulting and clinical psychology, 42, 909-910.

James C. coalman; (1988). Abnormal psychology and modern life, university of California at Los Angeles ,Copyright by D. B. Taraporevala Sons \& co. private ltd .85-134,722-732. 
Katon W. \& Ciechanowski, P. (2002). Impact of major depression on chronic medical illness. J Clin, J Psychosom 859-863.

Katon ,W. \& Suillivan M. D. (1990). Depression and chronic medical illness. J clin Psychiatriy.3-11.

Langone M. D. (1993). recovery from cults: help for victims of psychological and spiritual abuse. New York : Norton.

Major B. \& Razow R. H. (1999). Abortion as stigma: cognitive and emotional Implications of concealment. 735-745.

McGillivray, Mark. (2007). Human Well-being: Issues, Concepts and Measures. In Mark

McGillivray, Human Well-Being: Concept and Measurement. Basingstoke, Palgrave MacMillan, UK.

National institute of mental health retrieved. September 3(2008).

Nolen, S. \& Hoeksema (2001). Gender Differences in Depression. Department of Psychology, University of Michigan, Ann Arbor, Michigan: copyright 2001, American Psychological Society.

Robinson, M. D., \& Ryff, C. D. (1999). The role of self-deception in perceptions of past, present, and future happiness. Personality \& Social Psychology Bulletin, 25(5), 595-606.

Ryff, C. D. (1995). Psychological well-being in adult life. Current Directions in Psychological Science, 4, 99-104.

Ryff, C. (1989). Happiness is everything, or is it? Explorations on the meaning of psychological well-being. Journal of Personality and Social Psychology, 57, 1069-1081.

Ryff, C. D., \& Keyes, C. L. M. (1995). The structure of psychological well-being revisited. Journal of Personality \& Social Psychology, 69(4), 719-727.

Salmans, Sandra (1997). Depression: Questions You Have - Answers You Need. People's Medical Society, 978-1-882606-14-6.

Sanjay T V, Jahnavi R, Gangaboraiah B, Lakshmi P, Jayanthi S.(2014). Prevalence and factors influencing depression among elderly living in the urban poor locality of Bengaluru city. International Journals Health Allied Science, 3:105-9.

Schwarz, N., \& Strack, F. (1991). Evaluating one's life: A judgement model of subjective wellbeing. In F. Strack, M. Argyle, \& N. Schwarz (Eds.), Subjective Well-being: an interdisciplinary perspective. Oxford : Oxford University Press,pp.27-48.

Singer, M. et al, (1986). "Report of the APA task force on deceptive and indirect techniques of persuasion and control ( DIMPAC report)” American Psychological Association.

Spring (2005). The Ryff Scales of Psychological Well-Being. University of Iowa.

Waterman, A.S. (1993). Two conceptions of Happiness: Contrasts of personal expressiveness (Eudaimonia) and Hedonic Enjoyment. Journal of Personality and Social Psychology, 64 (4), 678-691.

W H O (1993). International statistical classification of diseases. 